\title{
KEPATUHAN WAJIB PAJAK MEMEDIASI DETERMINAN PENERIMAAN PAJAK PENGHASILAN
}

\author{
Rachmawati Meita Oktaviani, Pancawati Hardiningsih,dan Ceacilia Srimindari \\ Fakultas Ekonomika Dan Bisnis Universitas Stikubank \\ Email: meita.rachma@gmail.com
}

\begin{abstract}
This study aims to examine and analyze the factors affecting income tax revenues with tax compliance as an intervening variable. The study consists of three independent variables that tax penalties, the service tax authorities, and awareness of the taxpayer. While this research is tied in income tax revenues and intervening variable is tax compliance.This study used purpose sampling technique and survey method with questionnaires in collecting data. Respondent were sampled in this study is an individual taxpayer who performs is 120 respondent in Semarang. Research data analysis using multiple analysis with the path analysis. The results showed that the variable tax penalties and service tax authorities an effect on tax compliance, awareness taxpayer has no effect on tax compliance, tax penalties, awareness of taxpayers and taxpayer compliance effect on income tax revenue, the service tax authorities had no effect on tax revenue income. Tax compliance successfully mediate the relationship between the variables of service tax authorities against income tax revenue. Tax compliance not successfully mediate the relationship between the tax penalties and awareness taxpayer against income tax revenue.
\end{abstract}

Keywords: tax penalties, service tax authorities, awareness tax payer, tax compliance, income tax revenue

\begin{abstract}
Abstrak: Penelitian ini bertujuan untuk menguji dan menganalisis faktor yang mempengaruhi penerimaan pajak penghasilan dengan kepatuhan wajib pajak sebagai variabel pemediasi. Penelitian ini terdiri dari tiga variabel bebas yaitu sanksi perpajakan, pelayanan fiskus, dan kesadaran wajib pajak. Sedangkan terikat dalam penelitian ini adalah penerimaan pajak penghasilan dan variabel pemediasi adalah kepatuhan wajib pajak.Penelitian ini menggunakan teknik purpose sampling dan metode survey dengan kuesioner dalam pengumpulan datanya. Responden yang dijadikan sampel dalam penelitian ini adalah wajib pajak orang pribadi yang melakukan pekerjaan bebas sejumlah 120 responden di Semarang. Analisis data penelitian menggunakan regresi berganda dengan uji jalur (path analysis).Hasil penelitian menunjukan bahwa variabel sanksi perpajakan dan pelayanan fiskus berpengaruh terhadap kepatuhan wajib pajak, kesadaran wajib pajak tidak berpengaruh terhadap kepatuhan wajib pajak, sanksi perpajakan, kesadaran wajib pajak, dan kepatuhan wajib pajak berpengaruh terhadap penerimaan pajak penghasilan, pelayanan fiskus tidak berpengaruh terhadap penerimaan pajak penghasilan. Kepatuhan wajib pajak berhasil memediasi hubungan antara variabel pelayanan fiskus terhadap penerimaan pajak penghasilan. Kepatuhan wajib pajak tidak berhasil memediasi pengaruh sanksi perpajakan dan kesadaran wajib pajak terhadap penerimaan pajak penghasilan.
\end{abstract}

Kata Kunci: Sanksi Perpajakan, Pelayanan Fiskus, Kesadaran Wajib Pajak, Kepatuhan Wajib Pajak, Penerimaan Pajak Penghasilan 


\section{PENDAHULUAN}

Pembangunan nasional adalah kegiatan yang berlangsung terus-menerus dan berkesinambungan yang mana bertujuan untuk meningkatkan kesejahteraan masyarakat. Dalam melaksanakan pembangunan pasti ada masalah tentang pembiayaan, dimana pembiayaan ini direalisasikan ke dalam Anggaran Pendapatan dan Belanja Negara (APBN). APBN memenuhi kebutuhan dana dengan mengandalkan dua sumber pokok, yaitu sumber dana luar negeri dan dalam negeri. Sumber dana luar negeri salah satunya adalah hibah, sedangkan sumber dana dalam negeri misalnya penjualan migas, non migas dan pajak.Pajak merupakan suatu kewajiban bagi seluruh warga negara. Penerimaan pajak salah satunya dari Pajak Penghasilan (PPh). Pajak penghasilan merupakan suatu pungutan resmi yang ditujukan kepada masyarakat yang berpenghasilan atau atas penghasilan yang diterima dan diperolehnya dalam tahun pajak untuk kepentingan negara dan masyarakat dalam hidup berbangsa dan bernegara sebagai suatu kewajiban yang dilaksanakannya.Penerimaan pajak penghasilan tentunya dapat meningkat apabila didukung oleh semua pihak yang terkait, dalam perpajakan unsur utama adalah fiskus atau pemeriksa pajak dan juga wajib pajak. Terdapat beberapa faktor yang dapat mempengaruhi penerimaan pajak penghasilan antara lain sanksi perpajakan terhadap wajib pajak, pelayanan fiskus, kesadaran, serta kepatuhan wajib pajak.

Sanksi perpajakan diberikan kepada wajib pajak yang melanggar atau tidak patuh terhadap peraturan perpajakan. Setyoningrum(2015) dan Mutia(2014), menyatakan bahwa sanksi perpajakan mempengaruhi kepatuhan wajib pajak.Tiraada(2013), menyatakan bahwa sanksi perpajakan dapat mempengaruhi penerimaan pajak penghasilan. Dalam penelitian Winerungan(2013), menyatakan bahwa sanksi perpajakan tidak berpengaruh terhadap kepatuhan wajib pajak orang pribadi, sedangkan Mutia(2014) menyatakan bahwa sanksi perpajakan mempunyai pengaruh terhadap kepatuhan wajib pajak. Amanda(2014) menyatakan hal yang berbeda, bahwa sanksi perpajakan tidak mempunyai pengaruh positif terhadap kepatuhan wajib pajak.

Pelayanan fiskus diberikan dengan tujuan untuk membantu, mengurus, atau menyiapkan segala keperluan yang dibutuhkan seseorang dalam hal ini adalah wajib pajak dalam melakukan kewajiban pajaknya. Fiskus wajib memberikan pelayanan yang baik kepada wajib pajak agar wajib pajak merasa puas dan patuh terhadap peraturan perpajakan. Wajib pajak ketika diberikan pelayanan yang baik pasti secara langsung akan melakukan pelaporan SPT dengan tepat waktu dan sesuai prosedur, tapi sebaliknya jika wajib pajak merasa kurang mendapat pelayanan yang baik dari fiskus maka keinginan wajib pajak untuk melaporkan SPT menurun sehingga kepatuhan wajib pajak ikut menurun. Setyoningrum(2015), Amanda(2014), dan Mutia(2014) menyatakan bahwa pelayanan fiskus berpengaruh positif terhadap kepatuhan wajib pajak

Burton(2005)menyebutkan, kesadaran wajib pajak juga menjadi faktor penting dalam penerimaan pajak. Penelitian yang dilakukan oleh Tiraada(2013) dan Mutia(2014) menyatakan bahwa kesadaran wajib pajak mempunyai pengaruh terhadap kepatuhan wajib pajak. Menurut penelitian yangdilakukan oleh Amanda(2014) menyatakan hal yang sebaliknya, kesadaran wajib pajak tidak mempunyai pengaruh terhadap kepatuhan wajib pajak.

Kepatuhan wajib pajak dapat memberikan manfaat yang baik bagi penerimaan pajak penghasilan suatu Negara(Andreoni et al., 1998). Wajib pajak dikatakan patuh jika mereka sudah dan mampu menghitung membayar dan melaporkan perpajakan mereka sebagai 
wajib pajak dengan benar ke Direktorat Jendral Pajak sesuai dengan ketentuan. Komarawati(2011) dan Alfian(2012) menyatakan bahwa kepatuhan wajib pajak tidak mempengaruhi penerimaan pajak penghasilan. Jika wajib pajak sudah memahami tentang sanksi perpajakan, dan wajib pajak juga mempunyai kesadaran yang tinggi akan kewajibannya untuk ikut serta berkontribusi dalam pendapatan Negara dengan cara membayar pajak dan patuh terhadap ketentuan perpajakan serta fiskus dapat memberikan pelayanan yang baik kepada wajib pajak maka itu akan berpengaruh positif terhadap penerimaan pajak penghasilan.

\section{KAJIAN TEORI}

Atribusion Theory. Teori atribusi pertama kali ditemukan olehHeider(1958). Teori atribusi mengasumsikan bahwa orang mencoba untuk menentukan mengapa orang melakukan apa yang mereka lakukan, yaitu atribusi menyebabkan perilaku. Seseorang berusaha untuk memahami mengapa orang lain melakukan sesuatu yang mungkin satu atau lebih atribut menyebabkan perilaku itu. Teori atribusi dibagi menjadi tiga jenis menurut Robbin, yaitu:1).Kekhususan: Seseorang akan mempersepsikan perilaku individu lain secara berbeda dalam situasi yang berlainan. Apabila perilaku sesorang dianggap suatu hal yang luar biasa, maka individu lain yang bertindak sebagai pengamat akan memberikan atribusi eksternal terhadap perilaku tersebut. Sebaliknya, jika hal itu dianggap hal yang biasa, maka akan dinilai sebagai atribusi internal; 2).Konsensus: Jika semua orang mempunyai kesamaan pandangan dalam merespon perilaku seseorang dalam situasi yang sama. Apabila konsensusnya tinggi, maka termasuk atribusi internal. Sebaliknya jika konsensusnya rendah, maka termasuk atribusi eksternal; 3).Konsistensi: Jika seorang menilai perilaku-perilaku orang lain dengan respon sama dari waktu ke waktu. Semakin konsisten perilaku itu, orang akan menghubungkan hal tersebut dengan sebab-sebab internal.Kepatuhan wajib pajak terkait dengan sikap wajib pajak dalam membuat penilaian terhadap pajak itu sendiri. Teori atribusi sangat relevan untuk menerangkan kondisi internal maupun eksternal wajib pajak dalam memenuhi kewajibannya membayar pajak. Seseorang taat membayar pajak dilihat dari kondisi internal maupun eksternalnya, begitu pula sebaliknya.

Pajak Penghasilan (PPh). Pajak merupakan pendapatan bagi Negara yang berasal dari iuran seluruh masyarakat sesuai dengan pendapatan masing-masing yang diwajibkan dan bahkan dipaksakan kepada masyarakat yang memenuhi syarat sebagai wajib pajak dan pembayarannya bisa dilakukan secara langsung kepada aparat pajak. (Graetz \& Wilde, 1985; Kiryanto, 2000), menyebutkan pajak diwajibkan karena pajak merupakan penghasilan utama bagi Negara. Pajak dilakukan demi kesejahteraan masyarakat. Salah satu penerimaan pajak Negara adalah pajak penghasilan.

Pajak penghasilan adalah pungutan resmi pemerintah kepada masyarakat yang memiliki penghasilan atau penghasilan yang diterima atau diperoleh dalam tahun pajak. Pajak ini digunakan untuk penyelenggaraan pemerintah dan untuk kepentingan masyarakat (Komarawati, 2011). Pajak penghasilan dikenakan terhadap orang pribadi dan badan, berkenaan dengan penghasilan yang diterima atau diperoleh selama satu tahun pajak. Objek pajak penghasilan adalah penghasilan yaitu setiap tambahan kemampuan ekonomis yang diterima atau diperoleh wajib pajak, baik yang berasal dari Indonesia 
maupun dari luar Indonesia yang dapat dipakai untuk konsumsi atau untuk menambah kekayaan wajib pajak bersangkutan.

Sanksi Perpajakan. Sanksi perpajakan merupakan jaminan bahwa ketentuan peraturan perundang-undangan perpajakan (normaperpajakan) akan dituruti/ditaati/dipatuhi. Atau dengan kata lain sanksi perpajakan merupakan alat (preventif) agar wajib pajak tidak melanggar norma perpajakan (Mardiasmo, 2011). Pelaksanaan sanksi perpajakan diterapkan sebagai akibat tidak terpenuhinya kewajiban perpajakan oleh wajib pajak sebagaimana yang telah diatur oleh undang-undang perpajakan. Pelaksanaan sanksi perpajakan oleh wajib pajak dapat menyebabkan terpenuhinya kewajiban perpajakan oleh wajib pajak sehingga dapat meningkatkan kepatuhan wajib pajak. Wajib pajak akan patuh karena mereka memikirkan adanya sanksi berat berupa denda akibat tindakan illegal dalam usahanya menyelundupkan pajak (Ngadiman \& Huslan, 2015).

Pelayanan Fiskus. Pelayanan adalah suatu proses bantuan kepada orang lain dengan caracara tertentu yang memerlukan kepekaan dan hubungan interpersonal agar tercipta kepekaan dan keberhasilan. Pelayanan pelanggan bertujuan agar dicapainya kepuasan optimal pelanggan. Pelanggan yang dimaksud dalam penelitian ini adalah wajib pajak. Pelayanan yang baik kepada wajib pajak akan membangun image positif dalam diri wajib, sehingga mereka tidak lagi jera berhubungan dengan aparatur pajak. Pelayanan fiskus menurut peneliti sebelumnya (Murti,2014) adalah pemberian layanan (melayani) keperluan orang atau masyarakat yang mempunyai kepentingan pada organisasi itu sesuai dengan aturan pokok dan tata cara yang telah ditetapkan.

Kesadaran Wajib Pajak. Indonesia adalah negara yang menganut prinsip Self Assessment System dalam sistem perpajakan. Prinsip ini memberikan kepecayaan penuh kepada pembayar pajak unutk melaksanakan hak dan kewajibanya dalam bidang perpajakan, seperti yang tertuang dalam Ketentuan Umum dan tata Cara Perpajakan bahwa wajib pajak harus mengisi dan menyampaikan Surat Pemberitahuan dengan benar, lengkap, jelas, dan menandatanganinya.Kesadaran wajib pajak dapat dikatakan dengan empat dimensi, yaitu: persepsi wajib pajak, pengetahuan perpajakan, karakteristik wajib pajak dan penyuluhan perpajakan. Wajib pajak dikatakan sadar untuk membayar pajak ketika ia memiliki persepsi yang positif terhadap pajak, memiliki pengetahuan yang cukup tentang perpajakan, dan memiliki karakteristik yang patuh serta telah mendapatkan penyuluhan yang memadai(Csontos et al., 1998; Suryadi, 2006).

KepatuhanWajibPajak. Burton(2005)menyebutkan prinsip ini memaksa pembayar pajak harus memahami peraturan perundang-undangan mengenai perpajakan sehingga dapat melakukan tugas administrasi perpajakan. Dalam hal ini pembayar pajak harus mengisi sendiri Surat Pemberitahuan (SPT) yang dibuat pada setiap akhir masa pajak atau akhir tahun pajak.Fiskus hanya melakukan penelitian dan pemeriksaan mengenai kebenaran pemberitahuan tersebut, oleh karena itu wajib pajak dituntut untuk sangat memahami sistem perpajakan agar tercipta msyarakat yang sadar pajak dan mau memenuhi kewajibannya dalam perpajakan.Kepatuhanwajibpajakmenjadisyaratmutlak agar self assessment systemdapattercapaidenganbaik(Andreoni et al., 1998; Fischer et al., 1992; James \& Alley, 1989). 
Berdasarkan Peraturan Menteri Keuangan Nomor 192/PMK.03/2007, wajib pajak yang patuh adalah wajib pajak yang ditetapkan oleh Direktur Jederal Pajak sebagai wajib pajak yang memenuhi kriteria tertentu. Kriteria tersebut adalah sebagai berikut :1). Tepat waktu dalam penyampaian Surat Pemberitahuan (SPT), meliputi :a). Penyampaian SPT tahunan tepat waktu dalam 3 (tiga) tahun terakhir, b). Penyampaian SPT masa yang terlambat dalam tahun terakhir untuk masa pajak Januari sampai November tidak lebih dari 3 (tiga) masa pajak untuk setiap jenis pajak dan tidak berturut-turut, dan c). SPT masa yang terlambat sebagaimana dimaksud pada huruf $b$ telah disampaikan tidak lewat dari batas waktu penyampaian SPT masa pajak berikutnya; 2). Tidak mempunyai tunggakan pajak untuk semua jenis pajak, kecuali tunggakan pajak yang telah memperoleh izin mengangsur atau menunda pembayaran pajak, meliputi keadaan pada tanggal 31 Desember tahun sebelum penetapan sebagai wajib pajak patuh dan tidak termasuk utang pajak yang belum melewati batas akhir pelunasan; 3). Laporan keuangan diaudit oleh Akuntan Publik atau lembaga pengawasan keuangan pemerintah dengan pendapat wajar tanpa pengecualian selama 3 (tiga) tahun berturut-turut dengan ketentuan :a) Laporan keuangan yang diaudit harus disusun dalam bentuk panjang dan menyajikan rekonsiliasi laba rugi komersial dan fiskal bagi wajib pajak yang wajib menyampaiakan Surat Pemberitahuan Tahunan., dan b). Pendapat Akuntan atas laporan Keuangan yang diaudit ditandatangani oleh Akuntan Publik yang tidak sedang dalam pembinaan lembaga pemerintah pengawas Akuntan Publik; 4). Tidak pernah dipidana karena melakukan tindak pidana dibidang perpajakan berdasarkan putusan pengadilan yang telah mempunyai kekuatan hukum tetap dalam jangka waktu 5 (lima) tahun terakhir.

Pengembangan Hipotesa. Bersumber pada paparan diatas maka hipotesa yang dirumuskan dalam penelitian ini adalah sebagai berikut:a). $\mathrm{H}_{1}$ : sanksi perpajakan memiliki pengaruh positif terhadap kepatuhan wajib pajak, b). $\mathrm{H}_{2:}$ pelayanan fiskus memiliki pengaruh positif terhadap kepatuhan wajib pajak, c). $\mathrm{H}_{3}$ : pelayanan fiskus memiliki pengaruh positif terhadap kepatuhan wajib pajak, d). $\mathrm{H}_{4}$ : kepatuhan wajib pajak memiliki pengaruh positif terhadap penerimaan pajak penghasilan, e). $\mathrm{H}_{5}$ : sanksi perpajakan memiliki pengaruh positif terhadap penerimaan pajak penghasilan, f). $\mathrm{H}_{6}$ : pelayanan fiskus memiliki pengaruh positif terhadap penerimaan pajak penghasilan, g). $\mathrm{H}_{7}$ : kesadaran wajib pajak memiliki pengaruh positif terhadap penerimaan pajak penghasilan

\section{METODE}

Populasi dalam penelitian ini adalah wajib pajak orang pribadi di Kota Semarang.Sampel penelitian ini menggunakan purposive sampling dengan kriteria yaitu: (1)Wajib pajak orang pribadi yang mempunyai NPWP dan melakukan pelaporan SPT, dan (2) Wajib pajak yang melakukan pekerjaan bebas.

Metode Pengumpulan Data.Pengumpulan data primer dilakukan dengan metode survei menggunakan media angket (kuesioner). Sejumlah pernyataan yang tertera dalam lembar kuesioner diajukan kepada responden dan kemudian responden diminta untuk menjawab sesuai dengan pendapat mereka. Untuk mengukur pendapat responden digunakan skala Likert 1-5. 
InstrumenPenelitian. Pajak penghasilan.Pungutan resmi pemerintah kepada masyarakat yang memiliki penghasilan atau penghasilan yang diterima atau diperoleh dalam tahun pajak. Pajak ini digunakan untuk penyelenggaraan pemerintah dan untuk kepentingan masyarakat (Komarawati, 2011).Instrumen penelitian terdiri atas pertanyaan: 1).sanksi perpajakan yang tegas akan meningkatkan realisasi penerimaan pajak penghasilan, 2).penerimaan pajak penghasilan meningkat jika wajib pajak patuh dalam melaksanakan kewajibannya dalam perpajakan, 3).peningkatan efektifitas dan efisiensi dalam pemeriksaan pajak penghasilan dapat meningkatkan penerimaan pajak penghasilan, dan 4).penerimaan pajak penghasilan sepenuhnya digunakan untuk kepentingan masyarakat.

Sanksi Perpajakan. Sanksi perpajakan merupakan jaminan bahwa ketentuan peraturan perundang-undangan perpajakan (normaperpajakan) akan dituruti/ditaati/dipatuhi. Atau dengan kata lain sanksi perpajakan merupakan alat (preventif) agar wajib pajak tidak melanggar norma perpajakan (Mardiasmo, 2011).Instrumen penelitian terdiri atas pertanyaan: 1).sanksi akan diberikan jika terlambat atau tidak memenuhi kewajiban perpajakan, 2).sanksi akan diberikan jika menyembunyikan objek pajak, 3).sanksi administrasi dikenakan jika tidak membayar/kurang membayar pajak terutang saat jatuh tempo, 4).sanksi pidana diberikan jika dengan sengaja memperlihatkan dokumen palsu atau dipalsukan, dan 5).sanksi diberikan sesuai dengan ketentuan dan peraturan yang berlaku.

Pelayanan fiskus.Cara petugas pajak dalam membantu, mengurus, atau menyiapkan segala keperluan yang dibutuhkan seseorang yang dalam hal ini adalah wajib pajak (Winerungan, 2013). Instrumen penelitian terdiri atas pertanyaan: 1). Petugas menguasai peraturan berhubungan dengan pelayanan perpajakan, 2). Dalam memberikan pelayanan, petugas memperlihatkan kecepatan proses pelayanan dan kesesuaian prosedur, 3).penyuluhan yang dilakukan oleh petugas pajak dapat membantu pemahaman mengenai hak dan kewajiban selaku wajib pajak, 2). Petugas pajak senantiasa memperhatikan keberatan wajib pajak atas pajak yang dikenakan, 4). Petugas cepat tanggap terhadap masalah atau keluhan dariwajib pajak, 5). Petugas memberikan pelayanan perpajakan sampai tuntas, dan 6). Cara membayar dan melunasi pajak adalah mudah/efisien.

Kesadaran wajib pajak. Suatu kondisi dimana wajib pajak mengetahui, mengakui, menghargai dan mentaati ketentuan perpajakan yang berlaku serta memiliki kesungguhan dan keinginan untuk memenuhi kewajiban pajaknya.Instrumen penelitian terdiri atas pertanyaan: 1).pajak adalah iuran rakyat untuk dana pengeluaran umum pelaksanaan fungsi dan tugas Pemerintah, 2). Pajak merupakan sumber penerimaan Negara yang terbesar, 3).pajak merupakan bentuk partisipasi dalam menunjang pembangunan Negara, 4).penundaan pembayaran pajak dan pengurangan beban pajak sangat merugikan Negara, 5).pajak ditetapkan dengan Undang-undang dan dapat dipaksakan.

Kepatuhan Wajib Pajak. Instrumen penelitian terdiri atas pertanyaan: Instrumen penelitian terdiri atas pertanyaan: 1). menyediakan data-data yang lengkap ketika pemeriksaan pajak dilakukan, 2). Mengisi formulir pajak dengan lengkap dan jelas, 3). Menghitung pajak yang terutang dengan jumlah yang benar, 4). Membayar pajak yang terutang dengan tepat pada waktunya, 5). Selalu tepat waktu dalam menyampaikan surat 
pemberian (SPT), 5). Membayar pajak sesuai dengan tarif yang dibebankan, dan 6). Tidak melakukan penunggakan dalam membayar pajak.

Metode Analisis Data. Hipotesis dalam penelitian ini akan diuji dengan analisis regresi linier berganda, persamaan umum regresi linier berganda untuk satu variabel independen yaitu sanksi perpajakan, pelayanan fiskus, dan kesadaran wajib pajak. model yang digunakan untuk menguji pengaruh variabel-variabel secara spesifik terhadap tingkat penerimaan pajak penghasilan dan kepatuhan wajib pajak dalam penelitian ini dinyatakan dalam persamaan regresi dibawah ini :

$$
\begin{aligned}
& Y_{1}=\alpha+\beta_{1} X_{1}+\beta_{2} X_{2}+\beta_{3} X_{3}+e \\
& Y_{2}=\alpha+\beta_{4} Y_{1}+\beta_{5} X_{1}+\beta_{6} X_{2}+\beta_{7} X_{3}+e
\end{aligned}
$$

Keterangan : $\alpha=$ Kostanta; $\mathrm{Y}_{1}=$ KepatuhanWajibPajak; $\mathrm{Y}_{2}=$ PenerimaanPajakPenghasilan; $\beta_{1} X_{1}=$ SanksiPerpajakan; $\beta_{2} X_{2}=$ PelayananFiskus; $\beta_{3} X_{3}=$ Kesadaran Wajib Pajak; e = Standar Error / Kesalahan.

\section{HASIL DAN PEMBAHASAN}

Deskripsi Sampel. Gambaran umum responden dapat dilihat melalui demografi responden. Demografi responden pada penelitian ini meliputi nama wajib pajak, jenis kelamin, umur, pendidikan terakhir.

Tabel 1. Deskripsi Sampel Jenis Kelamin

\begin{tabular}{llcc}
\hline Data deskripsi & Keterangan & Jumlah & Presentase \\
\hline \multirow{2}{*}{ Jeniskelamin } & Laki-laki & 61 & $50,83 \%$ \\
& Perempuan & 59 & $49,17 \%$ \\
& Jumlah & 120 & $100 \%$ \\
\hline
\end{tabular}

Berdasarkan tabel 1., diketahui responden yang berjenis kelamin laki-laki sebanyak 61 orang atau $50,83 \%$ dan sisanya berjenis kelamin perempuan sebanyak 59 orang atau $49,17 \%$.

Tabel 2. Deskripsi Sampel Pendidikan Terakhir

\begin{tabular}{clcc}
\hline Data deskripsi & Keterangan & Jumlah & Presentase \\
\hline \multirow{2}{*}{ Pendidikan } & SMA & 27 & $22,50 \%$ \\
Terakhir & D3 & 34 & $28,33 \%$ \\
& S1 & 59 & $49,17 \%$ \\
& Jumlah & 120 & $100 \%$ \\
\hline
\end{tabular}

Berdasarkan Tabel 2. Diketahui responden yang tingkat pendidikan terakhir SMA sebanyak 27 orang atau 22,50\%, D3 sebanyak 34 orang atau 28,33\%, dan S1 sebanyak 59 orang atau $49,17 \%$.

Deskripsi Variabel. Untuk memperoleh gambaran tentang tanggapan responden tentang sanksi perpajakan, pelayanan fiskus, kesadaran wajib pajak, kepatuhan wajib pajak, dan penerimaan pajak penghasilan dilakukan pengujian terhadap perhitungan statistik deskriptif. 
Tabel 3. Statistik Deskriptif Variabel

\begin{tabular}{lccccr}
\hline \multicolumn{7}{c}{ Descriptive Statistics } \\
\hline Sanksi Perpajakan & N & Minimum & Maximum & Mean & Std. Deviation \\
Pelayanan Fiskus & 120 & 2.00 & 5.00 & 3.9283 & .52997 \\
Kesadaran Wajib Pajak & 120 & 2.71 & 5.00 & 3.9496 & .53381 \\
Kepatuhan Wajib Pajak & 120 & 2.80 & 5.00 & 3.8467 & .54494 \\
Penerimaan Pajak & 120 & 2.86 & 5.00 & 4.0343 & .41156 \\
Penghasilan & 120 & 2.50 & 5.00 & 3.9208 & .54617 \\
Valid N (listwise) & & & & & \\
\hline
\end{tabular}

Berdasarkan Tabel 3. output tampilan SPSS diatas menunjukkan bahwa jumlah responden sebanyak 120 responden. Variabel sanksi perpajakan mempunyai nilai terendah 2,00 dan tertinggi 5,00 dengan rata-rata 3,92, sedangkan nilai standar deviasi sebesar 0,53. Skala penilaian variabel sanksi perpajakan dalam penelitian ini adalah 1 sampai 5 sehingga nilai tengahnya adalah 3 . Sedangkan hasil penelitian menunjukkan bahwa ratarata jawaban responden adalah 3,92 > 3, hal ini bahwa responden mempunyai persepsi yang tinggi tentang sanksi perpajakan. Nilai standar deviasi sebesar 0,53 lebih kecil dibandingkan nilai rata-ratanya menunjukkan bahwa hasil tanggapan tidak berbeda jauh antar responden.

Variabel pelayanan fiskus mempunyai nilai terendah 2,71 dan tertinggi 5,00 dengan rata-rata sebesar 3,95, sedangkan nilai standar deviasi sebesar 0,53. Skala penilaian pelayanan fiskus dalam penelitian ini adalah 1 sampai 5 sehingga nilai tengahnya adalah 3 . Sedangkan hasil penelitian menunjukkan bahwa rata-rata jawaban responden adalah 3,95 $>3$, hal ini berarti bahwa responden mempunyai persepsi yang tinggi tentang pelayanan fiskus. Nilai standar deviasi sebesar 0,53 lebih kecil dibandingkan nilai rata-ratanya menunjukkan bahwa hasil tanggapan tidak berbeda jauh antar responden.

Variabel kesadaran wajib pajak mempunyai nilai terendah 2,80 dan tertinggi 5,00 dengan rata-ratanya 3,85, sedangkan nilai standar deviasi sebesar 0,54. Skala penilaian variabel kesadaran wajib pajak dalam penelitian ini adalah 1 sampai 5 sehingga nilai tengahnya adalah 3 . Sedangkan hasil penelitian menunjukkan bahwa rata-ratanya jawaban responden adalah 3,85>3, hal ini berarti bahwa responden mempunyai persepsi yang tinggi tentang kesadaran wajib pajak. Nilai standar deviasi sebesar 0,54 lebih kecil dibandingkan nilai rata-ratanya menunjukkan bahwa hasil tanggapan tidak berbeda jauh antar responden.

Variabel kepatuhan wajib pajak mempunyai nilai terendah 2,86 dan tertinggi 5,00 dengan rata-ratanya 4,03, sedangkan nilai standar deviasi sebesar 0,41. Skala penilaian variabel kepatuhan wajib pajak dalam penelitian ini adalah 1 sampai 5 sehingga nilai tengahnya adalah 3. Sedangkan hasil penelitian menunjukkan bahwa rata-ratanya jawaban responden adalah 4,03>3, hal ini berarti bahwa responden mempunyai persepsi yang tinggi tentang kepatuhan wajib pajak. Nilai standar deviasi sebesar 0,41 lebih kecil dibandingkan nilai rata-ratanya menunjukkan bahwa hasil tanggapan tidak berbeda jauh antar responden.

Variabel penerimaan pajak penghasilan mempunyai nilai terendah 2,50 dan tertinggi 5,00 dengan rata-ratanya 3,92, sedangkan nilai standar deviasi sebesar 0,55. Skala penilaian variabel penerimaan pajak penghasilan dalam penelitian ini adalah 1 sampai 5 sehingga nilai tengahnya adalah 3 . Sedangkan hasil penelitian menunjukkan bahwa rata-rata jawaban responden adalah 3,92 > 3, hal ini berarti bahwa responden 
mempunyai persepsi yang tinggi tentang penerimaan pajak penghasilan. Nilai standar deviasi sebesar 0,55 lebih kecil dibandingkan nilai rata-ratanya menunjukkan bahwa hasil tanggapan tidak berbeda jauh antar responden.

Pengujian Asumsi Klasik. Pengujian pertama yang dilakukan adalah pengujian normalitas. Bersumber pada tabel 4 dan tabel 5 dapat disimpulkan bahwa data yang digunakan dalam penelitian ini terdistribusi normal.

Tabel 4. Uji Normalitas Persamaan I

One-Sample Kolmogorov-Smirnov Test

\begin{tabular}{llr}
\hline & & Unstandardized Residual \\
\hline $\mathrm{N}$ & & 120 \\
Normal Parameters ${ }^{\mathrm{a}, \mathrm{b}}$ & Mean & .0000000 \\
& Std. & 2.35242518 \\
& Deviation & \\
Most Extreme & Absolute & .102 \\
Differences & Positive & .102 \\
& Negative & -.064 \\
Kolmogorov-Smirnov Z & & 1.117 \\
Asymp. Sig. (2-tailed) & & .165 \\
\hline
\end{tabular}

a. Test distribution is Normal.

b. Calculated from data.

Tabel 5. Uji Normalitas Persamaan II

One-Sample Kolmogorov-Smirnov Test

\begin{tabular}{|c|c|c|}
\hline & & $\begin{array}{l}\text { Unstandardized } \\
\text { Residual }\end{array}$ \\
\hline $\mathrm{N}$ & & 120 \\
\hline \multirow[t]{2}{*}{ Normal Parameters } & Mean & .0000000 \\
\hline & Std. Deviation & 1.55000128 \\
\hline Most Extreme & Absolute & .076 \\
\hline \multirow[t]{2}{*}{ Differences } & Positive & .064 \\
\hline & Negative & -.076 \\
\hline Kolmogorov-Smirnov Z & & .830 \\
\hline Asymp. Sig. (2-tailed) & & .497 \\
\hline
\end{tabular}

Uji Multikolineritas bertujuan untuk menguji apakah model regresi ditemukan adanya korelasi antar vatiabel bebas. Bersumber pada Tabel 6 dan Tabel 7 dapat disimpulkan bahwa variabel yang digunakan dalam penelitian ini terbebas dari multikolineritas 
Tabel 6. Uji Multikolinieritas Persamaan I Coefficients

\begin{tabular}{lcc}
\hline \multirow{2}{*}{ Model } & \multicolumn{2}{c}{ Collinearity statistics } \\
\cline { 2 - 3 } & Tolerance & VIF \\
\hline Sanksi Perpajakan & 0.854 & 1.171 \\
Pelayanan Fiskus & 0.880 & 1.136 \\
Kesadaran Wajib Pajak & 0.807 & 1.239 \\
\hline
\end{tabular}

Tabel 7. Uji Multikolinieritas Persamaan II Coefficients

\begin{tabular}{lcc}
\hline \multicolumn{1}{c}{ Model } & \multicolumn{2}{c}{ Collinearity statistics } \\
& Tolerance & VIF \\
\hline Sanksi Perpajakan & 0.661 & 1.513 \\
Pelayanan Fiskus & 0.842 & 1.187 \\
Kesadaran Wajib Pajak & 0.804 & 1.244 \\
Kepatuhan Wajib Pajak & 0.667 & 1.499 \\
\hline
\end{tabular}

Uji Heteroskedastisitas. Uji heteroskedastisitas bertujuan untuk menguji apakah dalam model regresi terjadi ketidaksamaan variance dari residual satu pengamatan ke pengamatan yang lain.

Tabel 8. Hasil Uji Heteroskedastisitas Persamaan I

\begin{tabular}{lrrrrrr}
\hline & \multicolumn{2}{c}{$\begin{array}{c}\text { Unstandardized } \\
\text { Coefficients }\end{array}$} & \multicolumn{2}{c}{$\begin{array}{c}\text { Standardized } \\
\text { Coefficients }\end{array}$} & & \\
\cline { 2 - 5 } Model & \multicolumn{1}{c}{ B } & Std. Error & Beta & \multicolumn{1}{c}{ T } & Sig. \\
\hline (Constant) & 1.328 & .963 & & 1.380 & .170 \\
Sanksi Perpajakan & -.091 & .196 & -.046 & -.462 & .645 \\
Pelayanan Fiskus & -.114 & .192 & -.059 & -.594 & .554 \\
Kesadaran Wajib Pajak & .162 & .196 & .085 & .827 & .410 \\
\hline
\end{tabular}

a. Dependent Variable: abres

Tabel 9. Hasil Uji Heteroskedastisitas Persamaan II

\begin{tabular}{|c|c|c|c|c|c|}
\hline \multicolumn{6}{|c|}{ Coefficients $^{\mathbf{a}}$} \\
\hline \multirow[b]{2}{*}{ Model } & \multicolumn{2}{|c|}{$\begin{array}{l}\text { Unstandardized } \\
\text { Coefficients }\end{array}$} & \multirow{2}{*}{$\begin{array}{c}\text { Standardized } \\
\text { Coefficients } \\
\text { Beta } \\
\end{array}$} & \multirow[b]{2}{*}{$\mathrm{t}$} & \multirow[b]{2}{*}{ Sig. } \\
\hline & $\mathrm{B}$ & Std. Error & & & \\
\hline (Constant) & 1.671 & 1.101 & & 1.518 & .132 \\
\hline Sanksi Perpajakan & -.022 & .223 & -.011 & -.098 & .922 \\
\hline Pelayanan Fiskus & -.087 & .196 & -.045 & -.444 & .658 \\
\hline Kesadaran Wajib Pajak & .170 & .197 & .089 & .864 & .389 \\
\hline Kepatuhan Wajib Pajak & -.185 & .286 & -.074 & -.648 & .518 \\
\hline
\end{tabular}

a. Dependent Variable: abres_A

Bersumber pada Tabel 8. dan 9. diatas disimpulkan bahwa model regresi tidak mengandung adanya heteroskedastisitas. 
Analisis Regresi Linier Berganda. Analisis regresi digunakan untuk membangun suatu persamaan yang menghubungkan antara variabel terikat dengan variabel bebas dan sekaligus untuk menentukan nilai dugaanya. Dalam analisis regresi selain mengukur kekuatan hubungan antara dua variabel atau lebih, juga menunjukkan arah hubungan variabel dependen dan independen (Ghozali, 2011). Persamaan regresi linier berganda yang dipergunakan untuk menganalisis variabel tersebut sebagai berikut:

Tabel 10. Regresi Linier Berganda Persamaan I

\begin{tabular}{|c|c|c|c|c|c|c|}
\hline \multirow{2}{*}{\multicolumn{2}{|c|}{ Model }} & \multicolumn{2}{|c|}{$\begin{array}{c}\text { Unstandardized } \\
\text { Coefficients }\end{array}$} & \multirow{2}{*}{$\begin{array}{c}\text { Standardized } \\
\text { Coefficients }\end{array}$} & \multirow[b]{2}{*}{$\mathrm{t}$} & \multirow[b]{2}{*}{ Sig. } \\
\hline & & $\mathrm{B}$ & Std. Error & & & \\
\hline \multirow[t]{4}{*}{1} & (Constant) & 1.850 & .313 & & 5.905 & .000 \\
\hline & Sanksi Perpajakan & .371 & .064 & 478 & 5.819 & .000 \\
\hline & Pelayanan Fiskus & .143 & .062 & .185 & 2.289 & .024 \\
\hline & $\begin{array}{l}\text { Kesadaran Wajib } \\
\text { Pajak }\end{array}$ & .043 & .064 & .056 & .668 & .505 \\
\hline
\end{tabular}

Tabel 11. Regresi Linier Berganda Persamaan II

\begin{tabular}{|c|c|c|c|c|c|c|}
\hline \multirow{2}{*}{\multicolumn{2}{|c|}{ Model }} & \multicolumn{2}{|c|}{$\begin{array}{l}\text { Unstandardized } \\
\text { Coefficients }\end{array}$} & \multirow{2}{*}{$\begin{array}{c}\begin{array}{c}\text { Standardized } \\
\text { Coefficients }\end{array} \\
\text { Beta }\end{array}$} & \multirow[b]{2}{*}{$\mathrm{t}$} & \multirow[b]{2}{*}{ Sig. } \\
\hline & & $\mathrm{B}$ & Std. Error & & & \\
\hline \multirow[t]{6}{*}{2} & (Constant) & -.378 & .413 & & -.914 & .362 \\
\hline & Sanksi & .213 & .084 & 207 & 2.544 & .012 \\
\hline & Perpajakan & & & & & \\
\hline & Pelayanan Fiskus & .121 & .074 & .119 & 1.644 & .103 \\
\hline & $\begin{array}{l}\text { Kesadaran Wajib } \\
\text { Pajak }\end{array}$ & .252 & .074 & .252 & 3.411 & .001 \\
\hline & $\begin{array}{l}\text { Kepatuhan Wajib } \\
\text { Pajak }\end{array}$ & .499 & .107 & .376 & 4.641 & .000 \\
\hline
\end{tabular}

Uji Hipotesis (Uji t). Uji t dilakukan untuk mengetahui apakah secara parsial variabel independen mempengaruhi variabel dependen secara signifikan atau tidak. Hasil output dari SPSS dapat dilihat pada tabel 10. dan tabel 11. persamaan regresi linier berganda dengan hasil sebagai berikut:

Sanksi perpajakan terhadap kepatuhan wajib pajak. Dari hasil perhitungan didapat signifikansi variabel sanksi perpajakan terhadap kepatuhan wajib pajak sebesar 0,000. Apabila nilai signifikansi $<0,05$ ini berarti variabel sanksi perpajakan secara statistik berpengaruh positif signifikan terhadap kepatuhan wajib pajak. Dengan demikian dapat disimpulkan bahwa $\mathbf{H}_{\mathbf{1}}$ diterima.

Pengaruh pelayanan fiskus terhadap kepatuhan wajib pajak. Dari hasil perhitungan didapat signifikansi variabel pelayanan fiskus terhadap kepatuhan wajib pajak sebesar 0,024 . Apabila nilai signifikansi $<0,05$ ini berarti variabel pelayanan fiskus secara statistik berpengaruh positif signifikan terhadap kepatuhan wajib pajak. Dengan demikian dapat disimpulkan bahwa $\mathbf{H}_{2}$ diterima. 
Pengaruh kesadaran wajib pajak terhadap kepatuhan wajib pajak. Dari hasil perhitungan didapat nilai signifikansi variabel kesadaran wajib pajak terhadap kepatuhan wajib pajak sebesar 0,507. Apabila nilai signifikansi > 0,05 ini berarti variabel kesadaran wajib pajak secara statistik berpengaruh positif tidak signifikan terhadap kepatuhan wajib pajak. Dengan demikian dapat disimpulkan bahwa $\mathbf{H}_{3}$ ditolak.

Pengaruh kepatuhan wajib pajak terhadap penerimaan pajak penghasilan. Dari hasil perhitungan didapat nilai signifikansi variabel kepatuhan wajib pajak terhadap penerimaan pajak penghasilan sebesar 0,000. Apabila nilai signifikansi $<0,05$ ini berarti variabel kepatuhan wajib pajak secara statistik berpengaruh positif signifikan terhadap penerimaan pajak penghasilan. Dengan demikian dapat disimpulkan bahwa $\mathbf{H}_{4}$ diterima.

Pengaruh sanksi perpajakan terhadap penerimaan pajak penghasilan. Dari hasil perhitungan didapat nilai signifikansi variabel sanksi perpajakan terhadap penerimaan pajak penghasilan sebesar 0,012. Apabila nilai signifikansi $<0,05$ ini berarti variabel sanksi perpajakan secara statistik berpengaruh positif signifikan terhadap penerimaan pajak penghasilan. Dengan demikian dapat disimpulkan bahwa $\mathbf{H}_{5}$ diterima.

Pengaruh pelayanan fiskus terhadap penerimaan pajak penghasilan. Dari hasil perhitungan didapat nilai signifikansi variabel pelayanan fiskus terhadap penerimaan pajak penghasilan sebesar 0,104. Apabila nilai signifikansi $>0,05$ ini berarti variabel kepatuhan wajib pajak secara statistik berpengaruh positif tidak signifikan terhadap penerimaan pajak penghasilan. Dengan demikian dapat disimpulkan bahwa H6 ditolak.

Pengaruh kesadaran wajib pajak terhadap penerimaan pajak penghasilan. Dari hasil perhitungan didapat nilai signifikansi variabel kesadaran wajib pajak terhadap penerimaan pajak penghasilan sebesar 0,001 . Apabila nilai signifikansi $<0,05$ ini berarti variabel kesadaran wajib pajak secara statistik berpengaruh positif signifikan terhadap penerimaan pajak penghasilan. Dengan demikian dapat disimpulkan bahwa $\mathbf{H}_{7}$ diterima.

Pembahasan . Sanksi Perpajakan terhadap Kepatuhan Wajib Pajak. Pada hipotesis pertama dalam hasil pengujian dengan regresi berganda menunjukkan bahwa sanksi perpajakan berpengaruh positif signifikan terhadap kepatuhan wajib pajak. Hal ini sesuai dengan hipotesis yang diungkapkan diawal bahwa variabel sanksi perpajakan berpengaruh positif signifikan terhadap kepatuhan wajib pajak. Penelitian ini menunjukkan bahwa wajib pajak setuju sanksi perpajakan sesuai peraturan perundangundangan perpajakan dapat diberlakukan bagi wajib pajak yang melakukan pelanggaran atau melakukan kecurangan dalam melaksankan kewajiban perpajakannya.

Temuan ini mendukung teori atribusi. Sanksi pajak sangat terkait dengan aspek konsekuensi. Sanksi pajak dibuat agar wajib pajak mematuhi peraturan perpajakan. Kepatuhan wajib pajak akan ditentukan berdasarkan persepsi wajib pajak tentang seberapa kuat sanksi pajak mampu mendukung perilaku wajib pajak untuk taat pajak. Dengan adanya sanksi perpajakan maka wajib pajak akan memilih untuk melaporkan SPT nya tepat waktu dan sesuai dengan bataswaktu yang telah ditetapkan. Jika tidak dilakukan tepat waktu maka sudah dapat dipastikan wajib pajak akan dikenakan sanksi. Hasil penelitian ini sejalan dengan Setyoningrum (2015), Mutia(2014), dan Santioso \& Sugiarto (2010), menyatakan bahwa sanksi perpajakan 
berpengaruh positif terhadap kepatuhan wajib pajak. Wajib pajak akan lebih memilih turut/taat/patuh daripada harus dikenakan sanksi sebagai akibat melanggar peraturan perpajakan.

Pelayanan Fiskus terhadap Kepatuhan Wajib Pajak. Pada hipotesis kedua dalam hasil pengujian dengan regresi berganda menunjukkan bahwa pelayanan fiskus berpengaruh positif signifikan terhadap kepatuhan wajib pajak. Hal ini sesuai dengan hipotesis yang diungkapkan diawal bahwa variabel pelayanan fiskus berpengaruh positif signifikan terhadap kepatuhan wajib pajak. Penelitian ini menunjukkan bahwa wajib pajak merasa akan patuh jika pelayanan yang diberikan oleh fiskus dari Kantor Pelayanan Pajak (KPP) memuaskan. Kepuasaan akan layanan fiskus dapat dirasakan dari banyak aspek. Pelayanan yang memuaskan bisa dilihat dari keramahan Account Representative dalam melayani wajib pajak, kecepatan fiskus dalam memberikan pelayanan, danpenguasaan peraturan perpajakan yang berhubungan dengan pelayanan perpajakan.

Temuan ini mendukung teori atribusi konsistensi, ketika akan melakukan sesuatu individu akan memiliki keyakinan tentang harapan normatif dan motivasi dari orang lain untuk memenuhi harapan tersebut. Harapan normative dan motivasi ini sangat terkait dengan pelayanan fiskus. Adanya pelayanan yang baik dari petugas pajak, sistem perpajakan yang efisien dan efektif, serta penyuluhan-penyuluhan pajak dapat memotivasi wajib pajak agar taat pajak.Wajib pajak memiliki keyakinan memilih perilaku taat pajak. Pelayanan fiskus yang baik memang sangat diutamakan, agar wajib pajak secara langsung akan patuh terhadap peraturan perpajakan. Hasil penelitian ini sejalan dengan Setyoningrum (2015), Amanda(2014), dan Murti(2014), menyatakan bahwa pelayanan fiskus berpengaruh positif terhadap kepatuhan wajib pajak. Fiskus diharapkan memiliki kompetensi berupa keahlian (skiil), pengetahuan (knowledge), dan pengalaman (experience) terkait kebijakan perpajakan, administrasi pajak, dan perundang-undangan perpajakan.

Kesadaran Wajib Pajak terhadap Kepatuhan Wajib Pajak. Pada hipotesis ketiga dalam hasil pengujian dengan regresi berganda menunjukkan bahwa kesadaran wajib pajak berpengaruh positif tidak signifikan terhadap kepatuhan wajib pajak. Hal ini tidak sesuai dengan hipotesis yang diungkapkan diawal bahwa variabel kesadaran wajib pajak berpengaruh positif terhadap kepatuhan wajib pajak. Kesadaran sangatterkaitan dengan kemauan dalam diri wajib pajak.Ukuran kepatuhan wajib pajak adalah saat terpenuhinya semua kewajiban perpajakan. Hasil peneltian ini tidak sejalan dengan hasil penelitian yang dilakukan oleh Amanda(2014), Murti(2014), dan Tiraada(2013) menyatakan bahwa kesadaran wajib pajak berpengaruh terhadap kepatuhan wajib pajak.

Kepatuhan Wajib Pajak terhadap Penerimaan Pajak Penghasilan. Pada hipotesis keempat dalam hasil pengujian dengan regresi berganda menunjukkan bahwa kepatuhan wajib pajak berpengaruh positif signifikan terhadap kepatuhan wajib pajak. Hal ini sesuai dengan hipotesis yang diungkapkan diawal bahwa variabel kepatuhan wajib pajak berpengaruh positif signifikan terhadap penerimaan pajak penghasilan. Sejalan dengan teori atribusi yang menyebutkan bahwa kepatuhan yang telah ditunjukkan oleh wajib pajak adalah suatu upaya yang bertujuan untuk menunjukkan konsistensi diri. 
Sebagaimana telah dijelaskan diatas dalam perspektif peraturan perpajakan ukuran kepatuhan adalah jika seorang wajib pajak telah memenuhi self assessment system.Wajib pajak yang telah memenuhi kewajiban perpajakan mulai dariaspek menghitung, membayar, hingga melaporkan SPT tepat waktu sudah pasti dapat dikategorikan mempunyai tingkat kepatuhan yang baik. Dengan pemenuhan kewajibannya wajib pajak menunjukkan bahwa wajib pajak telah berpartisipasi dan menjadi bagian dalam peningkatan penerimaan pajak. Hasil penelitian ini tidak sejalan dengan hasil penelitian yang dilakukan oleh Komarawati(2011) dan Alfian(2012) menyimpulkan bahwa kepatuhan wajib pajak tidak berpengaruh negatif terhadap penerimaan pajak penghasilan.

Sanksi Perpajakan terhadap Penerimaan Pajak Penghasilan. Pada hipotesis kelima dalam hasil pengujian dengan regresi berganda menunjukkan bahwa sanksi perpajakan berpengaruh positif signifikan terhadap penerimaan pajak penghasilan. Hal ini tidak sesuai dengan hipotesis yang diungkapkan diawal bahwa sanksi perpajakan berpengaruh positif tidak signifikan terhadap penerimaan pajak penghasilan. Hal tersebut terjadi karena wajib pajak tidak memahami peraturan perpajakantermasuk sanksi perpajakan yang bisa dikenakan kepada wajib pajak jika tidak memenuhi kewajiban perpajakannya. Penelitian ini tidak sejalan dengan penelitian yang dilakukan oleh Safitri(2010) menyimpulkan bahwa sanksi perpajakan tidak berpengaruh terhadap penerimaan pajak penghasilan.

Pelayanan Fiskus terhadap Penerimaan Pajak Penghasilan. Pada hipotesis keenam dalam hasil pengujian regresi berganda menunjukkan bahwa pelayanan fiskus berpengaruh positif tidak signifikan terhadap penerimaan pajak penghasilan. Hal ini tidak sesuai dengan hipotesis yang diungkapkan diawal bahwa variabel pelayanan fiskus berpengaruh positif signifikan terhadap penerimaan pajak penghasilan. Hal tersebut terjadi karena kemungkinan wajib pajak tidak mendapat pelayanan yang memuaskan dari fiskus sehingga tingkat kepatuhan wajib pajak menurun dan berpengaruh terhadap tingkat penerimaan pajak penghasilan. Penelitian yang dilakukan oleh Ibtida(2010) menyimpulkan bahwa pelayanan fiskus berpengaruh positif signifikan terhadap penerimaan pajak penghasilan.

Kesadaran Wajib Pajak terhadap Penerimaan Pajak Penghasilan. Pada hipotesis ketujuh dalam hasil pengujian regresi berganda menunjukkan bahwa kesadaran wajib pajak berpengaruh positif signifikan terhadap penerimaan pajak penghasilan. Hal tersebut sesuai dengan hipotesis yang diungkapkan diawal bahwa variabel kesadaran wajib pajak berpengaruh positif signifikan terhadap penerimaan pajak penghasilan. Penelitian ini menunjukkan bahwa wajib pajak harus sadar akan pentingnya membayar pajak karena penerimaan negara paling besar berasal dari pajak dan ketika semua wajib pajak sadar akan pajak maka penerimaan pajak penghasilan meningkat. Penelitian ini sejalan dengan penelitian yang dilakukan oleh (Herryanto \& Arianto, 2013; Ibtida, 2010; Suryadi, 2006) menyimpulkan bahwa kesadaran wajib pajak berpengaruh positif signifikan terhadap penerimaan pajak penghasilan.

\section{Analisis Jalur (Path Analysis)}

\section{Analisis Jalur Model 1}




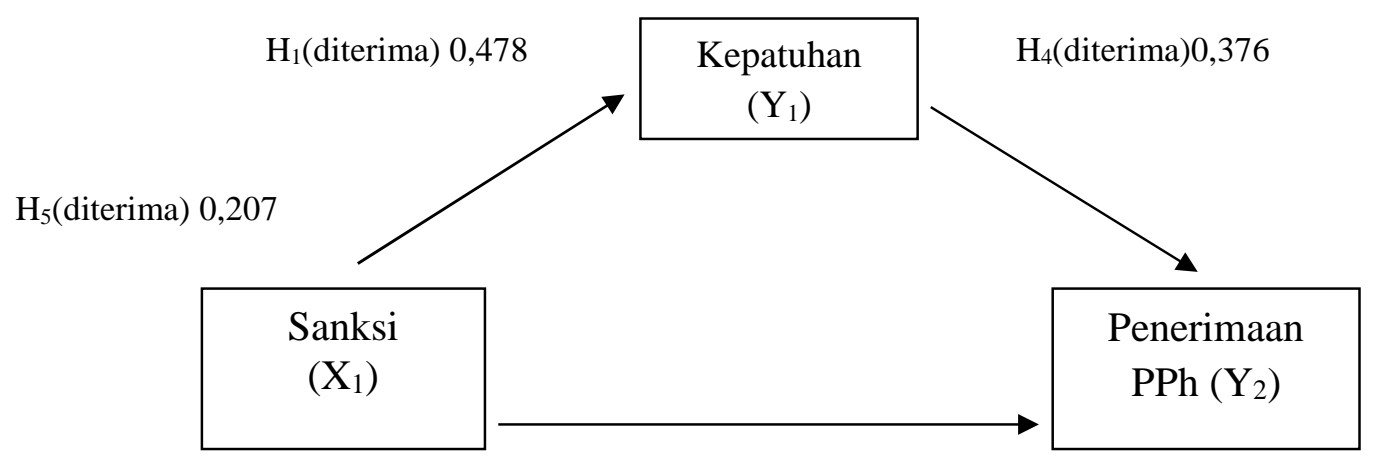

Gambar 1. Analisis Jalur Model 1

Pada Gambar 1 diatas menjelaskan bahwa sanksi perpajakan dapat berpengaruh langsung terhadap penerimaan pajak penghasilan dan berpengaruh tidak langsung terhadap penerimaan pajak penghasilan melalui kepatuhan wajib pajak. Hasil penelitian hipotesis menunjukkan bahwa sanksi perpajakan berpengaruh positif terhadap penerimaan pajak penghasilan sehingga hipotesis 5 signifikan 0,012 dinyatakan diterima. Pada hipotesis 1 menjelaskan sanksi perpajakan berpengaruh positif dengan signifikan 0,000 terhadap kepatuhan wajib pajak dan hipotesis ini diterima. Kepatuhan wajib pajak yang berpengaruh terhadap penerimaan pajak penghasilan pada hipotesis 4 dinyatakan diterima karena berpengaruh positif dan signifikan 0,000.

Hubungan langsung sanksi perpajakan terhadap penerimaan Pph dengan koefisien 0,207 sedangkan hubungan tidak langsung $(0,478 * 0,376)$ sebesar 0,179 . Bersumber pada konsep analisis jalur untuk model 1 nilai koefisien hubungan langsung lebih besar jika dibandingkan dengan hubungan tidak langsung maka dapat disimpulkan bahwa kepatuhan wajib pajak tidak memediasi hubungan sanksi perpajakan terhadap penerimaan PPh. Kepatuhan wajib pajak dalam model ini akan lebih tepat untuk menjadi variable bebas.

\section{Analisis Jalur Model 2}

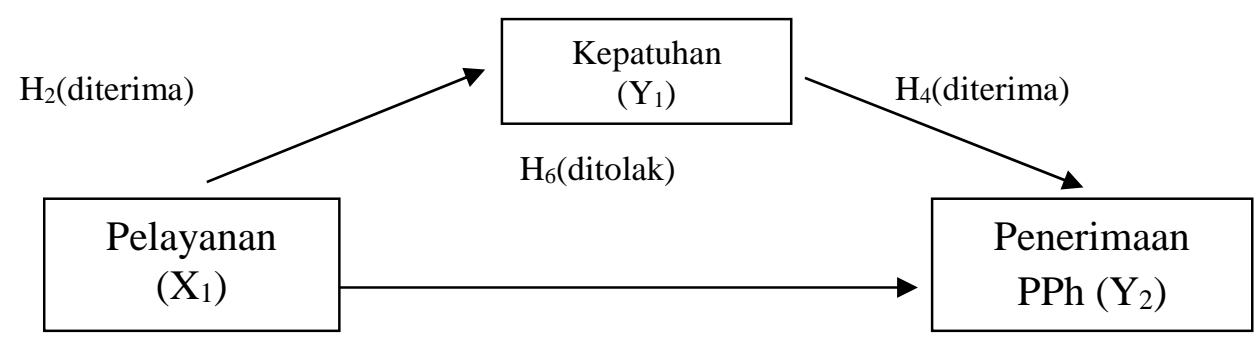

Gambar 2.Analisis Jalur Model 2

Pada gambar 2 diatas, hasil uji path menunjukkan bahwa pelayanan fiskus berpengaruh positif tidak signifikan terhadap penerimaan pajak penghasilan sehingga hipotesis 6 signifikan 0,104 dinyatakan ditolak. Pada hipotesis 2 menjelaskan pelayanan fiskus berpengaruh positif dengan signifikan 0,024 terhadap kepatuhan wajib pajak dan hipotesis ini diterima. Kepatuhan wajib pajak yang berpengaruh terhadap penerimaan pajak penghasilan pada hipotesis 4 dinyatakan diterima karena berpengaruh positif dan 
signifikan 0,000. Sehingga dapt disimpulkan kepatuhan wajib pajak dapat memediasi hubungan pelyanan fiskus terhadap penerimaan pajak penhasilan.

\section{Analisis Jalur Model 3}

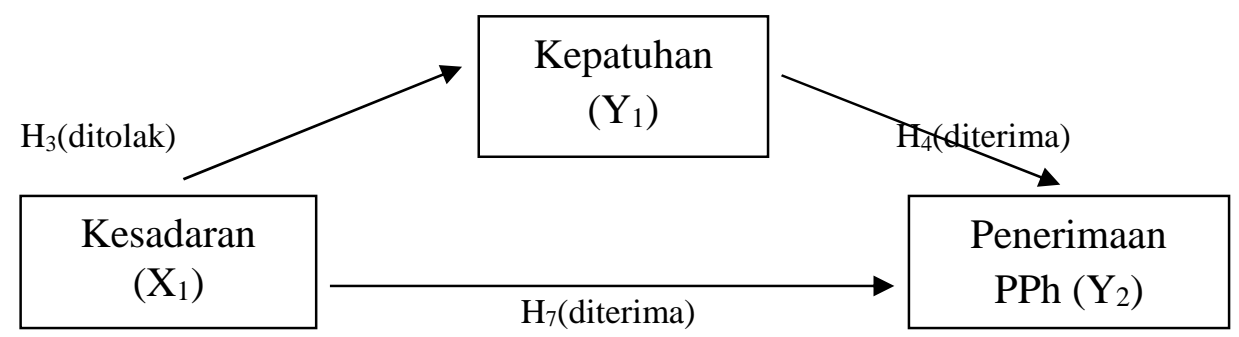

Gambar 3. Analisis Jalur Model 3

Pada gambar 3 diatas menjelaskan bahwa kesadaran wajib pajak dapat berpengaruh secara langsung terhadap penerimaan pajak penghasilan dan berpengaruh tidak langsung terhadap penerimaan pajak penghasilan melalui kepatuhan wajib pajak. Hasil penelitian hipotesis menunjukkan bahwa kesadaran wajib pajak berpengaruh positif terhadap penerimaan pajak penghasilan sehingga hipotesis 7 signifikan 0,001 dinyatakan diterima. Pada hipotesis 3 menjelaskan pelayanan fiskus berpengaruh positif dengan signifikan 0,507 terhadap kepatuhan wajib pajak dan hipotesis ini ditolak. Kepatuhan wajib pajak yang berpengaruh terhadap penerimaan pajak penghasilan pada hipotesis 4 dinyatakan diterima karena berpengaruh positif dan signifikan 0,000 .

\section{PENUTUP}

Simpulan. Sanksi perpajakan dan pelayanan fiskus berpengaruh signifikan terhadap kepatuhan wajib pajak sedangkan kesadaran wajib pajak tidak berpengaruh terhadap kepatuhan wajib pajak. Sanksi perpajakan, kesadaran pajak, dan kepatuhan wajib pajak berpengaruh signifikan terhadap penerimaan pajak penghasilan, sedangkan pelayanan fiskus tidak berpengaruh terhadap penerimaan pajak penghasilan. Kepatuhan wajib pajak berhasil memediasi pengaruh pelayanan terhadap penerimaan pajak penghasilan, tetapikepatuhan wajib pajak tidak berhasil memediasi pengaruh sanksi perpajakan dan kesadaran pajak terhadap penerimaan pajak penghasilan.

Keterbatasan Dan Saran. Variabel yang digunakan dalam penelitian ini hanya pada sanksi perpajakan, pelayanan fiskus, kesadaran wajib pajak, dan kepatuhan wajib pajak, sehingga masih ada variabel lain yang mempengaruhi penerimaan pajak penghasilan namun tidak masuk dalam penelitian ini.Sampel penelitian ini hanya dilakukan dari wajib pajak orang pribadi.

\section{DAFTAR RUJUKAN}


Alfian, R., (2012) Pengaruh Kepatuhan Wajib Pajak Orang Pribadi terhadap Penerimaan Pajak di KPP Pratama Surabaya Kembangan.

Amanda, C.P., (2014) Pengaruh Kesadaran Wajib Pajak, Sanksi Pajak, Pelayanan Fiskus, dan Pemeriksaan Pajak terhadap Kepatuhan Wajib Pajak Orang Pribadi di Kota Padang.

Andreoni, J., Erard, B., Feinstein, J., (1998) "Tax Compliance". Journal of Economic Literature. 36, 818-819.

Burton, R., (2005) "Menuju Wajib Pajak Patuh". Jurnal Perpajakan Indonesia. 5 (1), 811.

Csontos, L., Gy rgy, T., Kornai, J., (1998) "Tax Awareness And Reform Of The Welfare State: Hungarian Survey Results". Economics of Transition. 6 (2).

Fischer, C., M., Wartick, M., Mark, M., (1992) "Detection probability and taxpayer compliance: a review of the literature". Journal of Accounting Literature. 11, 1-46.

Ghozali, I., (2011) Aplikasi Analisis Multivariate dengan Program IBM SPSS 19. BP Universitas Diponegoro, Semarang.

Graetz, M.., Wilde, L.., (1985) "The economics of tax compliance: facts and fantasy". National Tax Journal. 38 (3), 355-364.

Heider, F., (1958) The Psychology of Interpersonal Relations. New York: Wiley.

Herryanto, M., Arianto, A., (2013) Pengaruh Kesadaran Wajib Pajak, Kegiatan Sosialisasi Perpajakan, dan Pemeriksaan pajak terhadap Penerimaan Pajak Penghasilan di KPP Pratama Surabaya Sawahan.

Ibtida, R., (2010) "Pengaruh Kesadaran Wajib Pajak dan Pelayanan Fiskus terhadap Kinerja Penerimaan Pajak dengan Kepatuhan Wajib Pajak senagai variabel Intervening", Skripsi. Surakarta.

James, S., Alley, C., (1989) "Tax Compliance, Self-Assessment and Tax Administration". Journal of Finance and Management in Public Service, 2 (2), 27-42.

Kiryanto, (2000) "Analisis Pengaruh Penerapan Struktur Pengendalian Intern Terhadap Kepatuhan Wajib Pajak Badan Dalam Memenuhi Kewajiban Pajak Penghasilannya". Jurnal Ekobis, 1(1), 41 - 52.

Komarawati, D.R., (2011) Analisis Tingkat Kepatuhan Wajib Pajak Orang Pribadi terhadap Tingkat Penerimaan Pajak di Kabupaten Lahat.

Mardiasmo, (2011) Perpajakan Edisi Revisi 2011. Penerbit Andi, Yogyakarta.

Murti, H., (2014) "Pelayanan Fiskus dan Pengetahuan Perpajakan terhadap Kepatuhan Wajib Pajak orang Pribadi di Kota Manado". Jurnal EMBA. 2 (3), 389-398.

Mutia, S.P., (2014) Pengaruh Sanksi Perpajakan, Kesadaran Perpajakan, Pelayanan Fiskus, dan Tingkat Pemahaman terhadap Kepatuhan Wajib Pajak Orang Pribadi.

Ngadiman, Daniel Huslan, (2015) "Pengaruh Sunset Policy,Tax Amnesty, Dan Sanksi Pajak Terhadap Kepatuhan Wajib Pajak (Studi Empiris di Kantor Pelayanan Pajak Pratama Jakarta Kembangan)". Jurnal Akuntansi. XIX (2), 225-241.

Safitri, A.H., (2010) Pengaruh Jumlah Pemeriksaan Pajak dan Sanksi Perpajakan terhadap Penerimaan Pajak Penghasilan dengan Kepatuhan Wajib Pajak sebagai Variabel Intervenig.

Santioso, L., Sugiarto, I., (2010) "Analisis Pengaruh Umur, Total Penghasilan, Bantuan Pihak Lain,Dan Sanksi Perpajakan Terhadap Kepatuhan Pajak". Jurnal Akuntansi. XIV (02), 235-245. 
Setyoningrum, A.T., (2015) Analisis Pengaruh Sosialisasi Perpajakan, Kualitas Pelayanan Fikus, dan Sanksi Perpajakan terhadap Kepatuhan Wajib Pajak di KPP Pratama manado.

Suryadi, (2006) "Model Hubungan Kausal Kesadaran, Pelayanan, Kepatuhan Wajib Pajak Dan Pengaruhnya Terhadap Kinerja Penerimaan Pajak". Jurnal Keuangan Publik, 4 (1), 105-121.

Tiraada, T., (2013) Kesadaran Perpajakan, Sanksi Pajak,Sikap Fiskus terhadap Kepatuhan WPOP di Kabupaten Minahasa Selatan, 1 (3), 999-1008.

Winerungan, Ok.L., (2013) "Sosialisasi Perpajakan, Pelayanan Fiskus,dan Sanksi Perpajakan terhadap Kepatuhan WPOP di KPP Manado dan KPP Bitung". Jurnal EMBA. 1 (3), 960-970. 